\title{
Explaining Taiwan's Economic Miracle: Are the Revisionists Right?
}

\author{
Pan-Long Tsai
}

In Taiwan between 1958 and 1963 when these policy revisions were being made, there was no idea that the economy was moving into an entirely new, externally oriented growth phase, and only with hindsight has the significance become obvious ... The policy switches were based on limited thinking about the immediate problems of unemployment and foreign exchange shortages. (Fei, 1995:47)

$\mathrm{T}$

ArWAN'S economic achievements over the past half-century have been remarkable (Table 1). The economy has been increasingly opened after the export drive of the 1960s and 1970s. Moreover, growth has not been achieved at the price of increasing inequality. The ratio of the incomes of the top 20 per cent of households to those of the lowest 20 per cent, estimated to be 20.47 in 1953 and 11.56 in 1961, has decreased to 5.33 in 1964 and never exceeded 6 since then, though it increased slightly in the 1990s (Chan \& Clark, 1992; Li, 1995).

Taiwan's transition from poverty to prosperity has been accompanied by profound structural changes (Table 2). Not only did the industrial content of exports accelerate from 15 per cent in the 1950s to 96 per cent in the 1990s, but skill- and capital-intensive commodities have gained prominence among Taiwan's exports.

Taiwan's economic success is also confirmed by the resilience it has demonstrated in the recent Asian crisis (Table 3). The Taiwanese economy performed well in the first half of 1998 . With some US\$84 billion of foreign reserves, relatively healthy banking regulation and an extremely light foreign-debt burden, it still augurs well for Taiwan to withstand the financial storm.

Taiwan was a basket case, militarily, politically, and economically, on the eve of the Korean War. While it was struggling to recover from the damage of World War II, it had to take in a sudden influx of $1.6-2 \mathrm{~m}$ refugees from the Chinese mainland, which increased its total population by over 25 per cent. The economy was further strained by one of the heaviest defence burdens in the world, reaching 9.5 per cent of GNP and 47 per cent of the government budget in 1961 (Chan \& Clark, 1992). Nevertheless, Taiwan managed to transform itself into a newly industrialising economy.

Pan-Long Tsai is Professor of Economics at National Tsing Hua University, Hsinchu, Taiwan. 
Table 1

Selected indicators of Talwan's economy, 1952-96

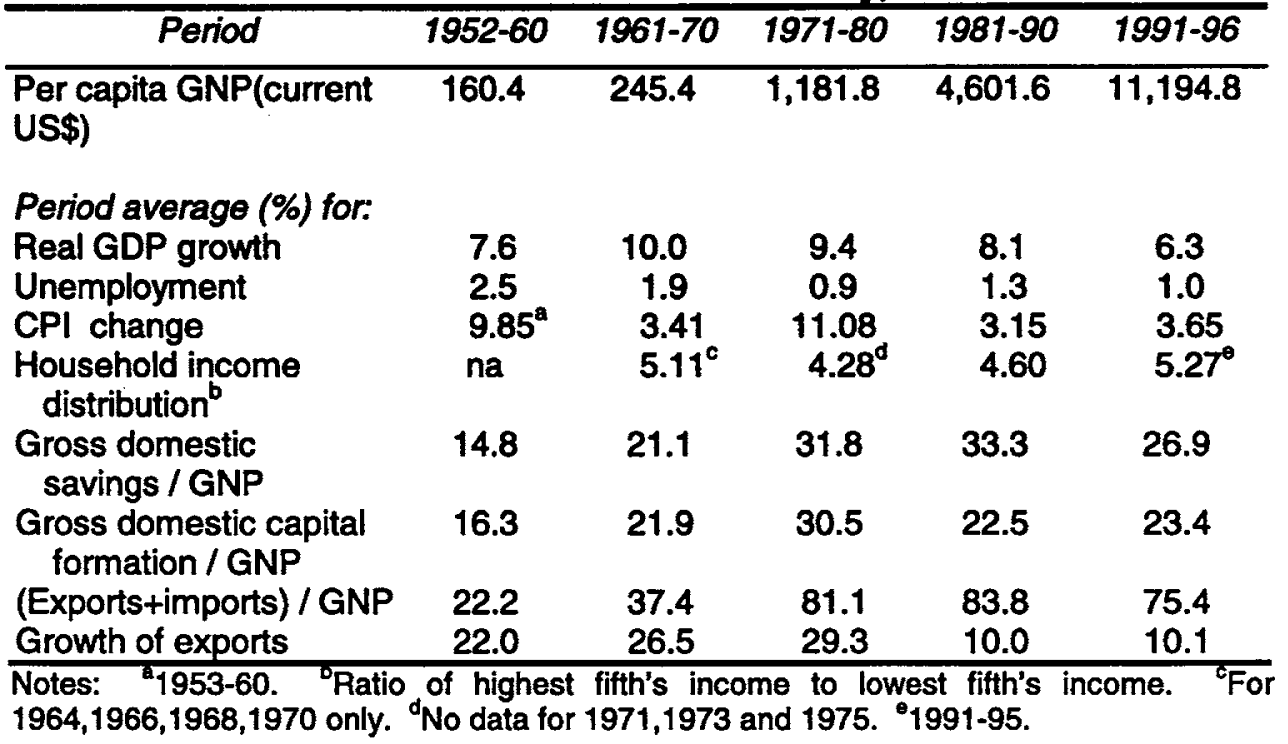

Sources: CEPD (1983, 1990, 1997); Li (1995:Appendix).

Table 2

Indicators of structural changes (per cent, period average)

\begin{tabular}{lccccc}
\hline \multicolumn{1}{c}{ Indicator } & $1952-60$ & $1961-70$ & $1971-80$ & $1981-90$ & $1991-96$ \\
\hline Composition of GDP & & & & & \\
Agriculture & 28.9 & 21.7 & 11.0 & 5.9 & 3.6 \\
Industry & 23.9 & 31.7 & 42.8 & 44.9 & 38.2 \\
Services & 47.3 & 46.6 & 46.2 & 49.2 & 58.2 \\
& & & & & \\
$\begin{array}{l}\text { Employment by industry } \\
\text { Agriculture }\end{array}$ & 53.0 & 44.9 & 28.2 & 16.3 & 11.4 \\
$\begin{array}{l}\text { Industry } \\
\text { Services }\end{array}$ & 18.7 & 23.4 & 36.2 & 41.9 & 39.0 \\
$\begin{array}{l}\text { Composition of exports } \\
\text { Agricultural products }\end{array}$ & 28.3 & 31.7 & 35.6 & 41.8 & 49.6 \\
$\begin{array}{l}\text { Processed agricultural } \\
\text { products }\end{array}$ & 19.0 & 14.3 & 5.6 & 1.6 & 0.5 \\
Industrial products & 65.8 & 29.9 & 8.2 & 4.5 & 3.6 \\
\hline
\end{tabular}

Sources: as for Table 1. 


\section{Table 3}

\begin{tabular}{lcccc}
\multicolumn{5}{c}{$\begin{array}{c}\text { Rate of change in currencies and stock prices (per cent) in nine } \\
\text { Asian countries (end June 1997 - end June 1998) }\end{array}$} \\
\hline \multicolumn{1}{c}{ Country } & $\begin{array}{c}\text { Currency } \\
\text { depreciation }\end{array}$ & $\begin{array}{c}\text { Stock price } \\
\text { fall }\end{array}$ & Total change & Rank \\
\hline Hong Kong & 0.0 & 43.8 & 43.8 & 7 \\
Indonesia & 83.6 & 38.5 & 122.1 & 1 \\
Japan & 18.3 & 23.2 & 41.5 & 8 \\
Korea & 35.3 & 60.0 & 95.3 & 3 \\
Malaysia & 39.0 & 57.7 & 96.7 & 2 \\
Philippines & 37.3 & 40.9 & 78.2 & 5 \\
Singapore & 15.4 & 46.3 & 61.7 & 6 \\
Taiwan & 19.0 & 16.4 & 35.4 & 9 \\
Thailand & 38.7 & 49.3 & 88.0 & 4 \\
\hline
\end{tabular}

Note: ${ }^{2}$ Currency depreciates against US dollar.

Source: The Liberty Times, 4 July 1998; data compiled by DGBAS.

\section{Explaining Taiwan's Success}

Over the past 30 years, different explanations have been advanced of the East Asian miracle in general, and Taiwan's in particular. While the debate is far from settled, there is a growing consensus that, besides a stable social and political environment, macroeconomic stability is fundamental to sustained growth. At the micro or structural level, however, much less agreement has been achieved (Lall, 1996; Tsai, 1997). The neoclassical paradigm holds that the successful East Asian economies shared crucial common characteristics; for instance, they all tended to 'get the prices right' and to rely on market signals for resource allocation, even if they did go beyond the pure neoclassical prescriptions of 'law and order and infrastructure'.'

By contrast, revisionists argue that the fast-growing East Asian economies owe their achievements less to economic liberalism than to selective industrial policies involving strategies of industrial targeting, 'getting prices wrong', 'picking winners', or even 'creating winners'. Wade (1990), for example, has documented the extensive employment of tariffs, quantitative restrictions, fiscal incentives and selective credit policies by the Taiwanese government during various stages of development.

In this article, some fundamental defects in the revisionist's arguments are highlighted.

\footnotetext{
'See for example Bhagwati (1978), Krueger (1978), World Bank (1993), and Hill (1996). For Taiwan, see Galenson (1979), Ranis (1995) and Riedel (1996).

In addition to Wade (1990), major contributors to this school of thought include Johnson (1982), Amsden (1989), Fishlow et al (1994) and Amsden (1994). Smith (1995) provides a very useful survey of the contending theories. See also Lall (1996) and Ranis (1996). The East Asian debate is not limited to the neoclassical and revisionist paradigms. For instance, Krugman (1994) claims that the growth was due simply to massive factor accumulation rather than productivity growth and thus there is nothing miraculous in the East Asian experience.
} 


\section{The Path of Taiwan's Industrial Development}

Primary import substitution (1952-57). Taiwan's industrial development since 1952 may be usefully divided into four phases: primary import substitution (1952-57), transition and export promotion (1958-72), secondary import substitution (197380 ), and promotion of strategic and high-tech industries (1981-present). ${ }^{3}$

The most well-documented policy initiative during the first phase was the land reform program carried out in 1949-1953 (Ho, 1978). It led to the rapid agricultural growth and the advancement of agricultural technology, which facilitated industrial development by providing it with agricultural surplus on the one hand and a sufficient market for industrial outputs on the other. Above all, the individualism of land reform had unexpectedly turned farmers into small modern economic agents. According to $\mathrm{Li}$ (1995), this is the source of Taiwan's economic miracle.

Like most developing countries in the 1950 s, Taiwan resorted to so-called primary or 'easy' import substitution (IS) (Lin, 1973; Ho, 1978). Unlike in most countries adopting this strategy, however, Taiwan's IS policy aimed largely at saving foreign exchange rather than self-sufficiency (Li, 1994; Kuo, 1997). A battery of interventions, including protective tariffs, quantitative import restrictions, foreign exchange controls and multiple exchange rates, was used to encourage domestic production of substitutes for imported goods such as textiles, cement and fertilisers. These policies, along with deficit financing, selective credit allocation, entry barriers, control of raw materials allocation and so forth, protected the domestic infant industries and made a significant impact on Taiwan's earlier development.

Transition and export promotion (1958-72). As is usually the case, the small protected domestic market was quickly saturated, and primary import substitution lost momentum. Real GNP growth rates fell every year during 1952-56; the growth rate of industrial output declined to 11 per cent and that of employment to 5 perr cent in the second half of the 1950s (Ranis, 1979). Hardly any foreign exchange was saved; in 1958, Taiwan was still running a trade deficit of some US $\$ 70 \mathrm{~m}$. These problems, along with increasing pressure from the United States, led ultimately to a wide-ranging reorientation of the development strategy. ${ }^{4}$ The most notable measures were the foreign exchange reform, the Nineteen-Point Economic and Fiscal Reform Programme (the 19-point programme hereafter), and the Statute for the Encouragement of Investment (SEI).

Under the foreign exchange reform adopted at the end of 1957, the multiple exchange-rate system was gradually dismantled and in 1963 the rate was set at NT\$

\footnotetext{
${ }^{3}$ For the initial conditions of Taiwan's industrial development and more detailed descriptions of the policy evolution, see Haggard and Pang (1994) and Dahlman and Sananikone (1997).

It is noteworthy that the reform had much earlier root. There were heated debates between the conservative camp and the industrialising reformers back in the carlier 1950s (Haggard \& Pang, 1994). In fact, some export promotion measures were initiated before this stage; for instance, a tax rebates system which reimbursed import duties on raw materials was introduced in 1954 (Kuo, 1997).
} 
40 to US\$1. The single exchange rate system ended the overvaluation of the New Taiwan dollar and paved the way for a decade of buoyant export expansion (Wang, 1993; Haggard \& Pang, 1994).

The 19-point programme of 1960 was intended 'to encourage saving and investment, to reduce expenditure and to promote exports'. It reviewed the various stopgap measures adopted in the past, with the aim of liberalising them and restoring market mechanisms; it established permanent economic institutions like the central banking system and capital market; and it provided preferential treatment to private business.

The SEI was designed to reduce the tax burden, to facilitate the acquisition of plant sites, and to simplify investment licensing procedures. At its core were tax incentives for exports, which were available for domestic as well as foreign investors. Within seven years, total tax exemption reached NT\$3 billions, and GNP jumped 235 per cent during 1960-67. Total foreign direct investment soared to US $\$ 34.2 \mathrm{~m}$ in 1960-63, up from US $\$ 10.9 \mathrm{~m}$ in $1952-59$. Until it was superseded by the Statute for Industrial Upgrading (SIU) at the end of 1990, the SEI was the most important piece of legislation promoting the industrial development of Taiwan. Other measures promoting exports were the liberalisation of the foreign exchange allocation system, a special export loan programme, import liberalisation, and the establishment of export processing zones. However, as Wade (1990) and Brautigam (1995) have argued, trade liberalisation was generally limited to the export sector, with the domestic market remaining heavily protected. Despite this, the transition toward export promotion still represented the most significant policy shift in Taiwan's postwar economic development.

Secondary import substitution (1973-80). Following a series of economic and political shocks in the 1970 s, there was a renewed emphasis on infrastructure as well as the role of state in the industrial development. In the Ten Major Construction Projects of 1974-78 the government invested some US\$5 billion in six transportation projects, several nuclear power plants, an integrated steel mill, a large shipyard, and several petrochemical plants. The last three projects on this list involved a policy of a secondary import substitution designed to establish a fully-fledged heavy and chemical industry (HCI). Also in 1973, the government set up the Industrial Technology Research Institute (ITRI), which received government contracts to conduct research programmes, develop key technologies and transfer the results to industry in a non-exclusive manner. Together with the Institute for Information Industry (III) established in 1979, ITRI played a leading role in both industrial technology and manpower development, and laid the foundation for the intense promotion of high-tech industries after the 1980 s.

Strategic and high-tech industries and liberalisation (1981-present). The 1979 oil shock, the worsening labour shortage, increasing environmental concerns, and mounting protectionist pressure from the US in the 1980s led to a major shift of the development strategy in general and industrial policy in particular. Some HCI proj- 
ects were postponed or cancelled, and other measures for industrial upgrading were adopted. First, following the announcement of the Ten Year Economic Development Projection (1980-89), a set of 'strategic' industries was selected according to the so-called 'two-large' (large linkage effects, large market potential), 'two-high' (high rate of value added, high technology intensity), and 'two-low' (low energy intensity, low pollution) criteria. Apart from the incentives in SEI, the government subsidised these industries through preferential medium- and long-term low interest loans and provided them with technology and management guidance (Smith, 1997a).

Second, the Science and Technology Development Programme launched in 1978-79 identified energy, materials, information and automation for development through national effort. Mimicking the model of Silicon Valley, the Hsinchu Science-Based Industrial Park (HSBIP) was established in 1980, and numerous measures were adopted to promote the growth of high-tech industries (Kuo, 1997). The success of the HSBIP led in 1995 to a second science park being approved in Tainan.

Third, the 1980s witnessed accelerated liberalisation. Foreign exchange was decontrolled in 1987, and capital movement was freed. Both interest rates and the exchange rate were largely (though not completely) deregulated. Most quantitative import controls were eliminated, and tariff protection was greatly reduced. As for industrial policy, the most important development was the replacement of the SEI by the Statute for Industrial Upgrading (SIU) in 1991. The SIU offers incentives such as accelerated depreciation and tax breaks for energy conservation and as industrial modernisation. These incentives are functional rather than being targeted to specific industries, as was the case under the SEI. This change reflects not only the increasing difficulties involved in pursuing selective policies as Taiwan's economy becomes more complex, but also the deepening integration of Taiwan in the world economy and the need to observe international policy norms.

\section{Picking Winners?}

As noted, the revisionists maintain that the East Asian miracle was brought about by planned strategies of industrial targeting, 'getting prices wrong', and 'picking' or 'creating winners'. This hypothesis has met the challenge of at least two tests. First, the motivation question: were the selective policies consciously planned, and the winners judiciously picked to reap some long-run dynamic comparative advantage anticipated by government officials? Second, the causation question: were the undoubtedly extensive selective interventions in Taiwan a major determinant of Taiwan's extraordinary growth? Wade himself is somewhat cautious on this point, conceding that 'The fact of big leadership or big followship does not mean that government intervention has been effective in promoting economic growth; it only means that government cannot be dismissed as having made a negligible difference to outcomes' (Wade, 1990:305). 
Land reform. There is little dispute about the far-reaching effects of the land reform on Taiwan's development. To assess its implications for the industrial development in Taiwan, however, more attention has to be paid to its motivation. It is extremely important to note that the top priority of the Kuomingtang (KMT) regime during the early 1950s was simply 'security' and 'survival'. The economic motivation was quite simply to feed the suddenly increased population by improving land productivity.

The political motives were more complicated and in some sense more important than the economic ones. First, the KMT recognised that one of the key reasons for its defeat on the mainland was its failure to carry out its promised land reform. It quickly undertook land reform in Taiwan to head off rural discontent stemming from the thirst for land by the poor peasants. Moreover, the reactivated farmer and irrigation associations were used to coopt the new class of small landholders into the KMT support base. Second, the land reform was designed also to crush the indigenous landlord class, the only group that could pose a challenge to the transplanted KMT regime. Third, a reliable food supply was vital for the eventual counterattack on the Chinese mainland that the KMT envisaged at the time. Fourth, land reform was part of the global anti-Communism strategy promoted by the US in the 1940s. These economic and political motives go far to explain why 'in the early 1950s, both Chinese land reformers, and their American advisers ... were never concerned with the possibility that reform might turn farmers into capitalists, and probably few of them thought of this as a consequence' $(\mathrm{Li}, 1995: 221)$.

Import substitution. Revisionists argue that various interventions and industrytargeting policies during the IS phase contributed significantly to Taiwan's industrial development. This could be true, but at best only with hindsight. During the 1950 s, there were few signs of any sensible vision about Taiwan's future development, let alone any conscious strategies. Again, policies tended to be adopted in response to impending problems. Large amounts of foreign exchange were required to import the fertiliser needed for higher food production, to import cloth, and to import cement for repairing the war-torn infrastructure. As a result, the fertiliser, textile and cement industries were targeted; and export industries reflecting Taiwan's comparative advantage, such as processed agricultural products, were encouraged.

As well as being a pragmatic response to the problems of the early 1950s, Taiwan's IS policy displayed several prominent characteristics. First was an emphasis on limited support to the targeted sectors and on the role of market, which made it perfectly consistent with the conventional infant industry argument. ${ }^{5}$ According to K.Y. Yin, the architect of Taiwan's economic policy in the 1950s:

\footnotetext{
5

${ }^{5}$ The revisionists tend to equate the neoclassical paradigm to absolute laissez faire, which is an unforunate mistake. Infant industry policy is perfectly legitimate in the neoclassical paradigm. What concerns orthodox economists is how the policy is carried out.
} 
The Government ... should give its support to those industries which it thinks must be developed and which are in need of its support. However, there should be a limit ... As to the development and growth of the various industries ... it is still the responsibility of the industries themselves. From the long-range point of view, if normal development is to be attained, free competition must be maintained in order to attain higher efficiency, eliminate uneconomical production ... Excessive support obviously hampers the operation of free competition and is bound to result in the creation of greenhouse industries dependent entirely upon the Government. (Yin, 1954:7)

Second, IS policy never completely ignored the export sector. In fact, against the conservative camp, Yin had insisted on promoting exports even in the very early days of the IS, partly to increase the flow of foreign exchange and partly to reduce the risk of inflation while accelerating capital accumulation through restraining domestic consumption (Wang, 1993).

Most important, Taiwan's IS strategy represented a move towards liberalisation. The KMT was from the beginning strongly committed to statism, which is why Taiwan's public enterprise sector was much more significant than those of the other newly industrialising countries. But gradually the KMT shifted from the doctrine of a 'planned economy' to one of 'planned free economy', culminating in the drastic policy reform of the late 1950s. The policy reorientation during 1958-63 had little to do with 'governing the market' or 'picking winners'. This could not be better illustrated than by the quotation at the start of this article.

The secondary IS. The increasing dirigisme during the phase of the secondary IS seems to fit the revisionists' interpretation of Taiwan's experience. Wade (1990:87) argues that 'The new direction of industrialisation was in fact mapped out long before the mid-1970s', citing passages from the Third Four-Year Plan (1961-64) and the Fourth Four-Year Plan (1965-68). It should be noted that, during the 1960s, many East Asian countries, including Indonesia, Cambodia, Thailand, Malaysia and the Philippines, had development or industrialisation plans of various lengths (Hsu, 1997). However, few of them developed successfully simply because of these plans. In the case of Taiwan, Fei (1992) observes that 'In actual practice, the planning ... was little more than a rough classification of all industries according to aphorisms imagined by the bureaucrats'. Tso-Jung Wang, K.Y. Yin's own chief economist and the drafter of the 19-point programme, sadly pointed out in 1968:

The key problem is that our Government never pays attention to economic planning ... If you do not believe, you might go to check the office of the vice-chairman of the Council for International Economic Cooperation and Development (CIECD), the Minister of Economic Affairs, the Minister of Finance ... and see whether you could find a copy of the Fourth Four-Year Plan. If you are unfortunate enough to find one, it is for sure that it will be 
covered with thick dust. But you know that they are the key figures giving all the directions during the process of making the plans; they are the highranking officers responsible for implementing the plans. (Cited in Lin, 1995:203; author's translation)

So why and how was the secondary IS policy finalised? The most important reason was the accession of Chiang Ching-Kuo to the vice-premiership and the chairmanship of CIECD in 1969. Chiang made decisions virtually alone. He was inclined to Soviet-type economic planning as well as to heavy industries, probably owing to his training in the USSR. To consolidate his political power, he initiated a wave of state-led industrialisation. In 1972 he became prime minister, and the following year announced the grandiose Ten Major Construction Projects, much to the surprise even of K.T. Li, the Minister of Finance who was responsible for financing them (Wang, 1993). The Projects turned out to contribute greatly to Taiwan's rapid recovery from the two oil crises and to economic growth thereafter. But they were by no means designed to counter business cycles or shocks (Kuo, 1997). The success was fortuitous, and, pace the revisionists, had nothing to do with any judicious selection.

High-tech industries. While progress from gradual to accelerating liberalisation has been the most important characteristic of the Taiwan economy since the early 1980s, revisionists often cite the government's active role in promoting high-tech industries as evidence of continuing dirigisme in Taiwan. It is argued that without the government's initiative and support, there would be no ITRI, no III, no Electronic Research Services Organisation, no HSBIP, and thus no semiconductor industry, no information industry, no United Microelectronics Corporation and no Taiwan Semiconductor Manufacturing Corporation. The argument is valid if we confine ourselves to a very special sector of the economy and to post-1970 development. But the high-tech semiconductor and information industries are only a part, however crucial, of the wider electrical and electronics industry. Hobday claims:

The Taiwanese Government's initial motive for encouraging electronics ... was to create employment, earn foreign exchange and exploit what was a fast-growing export opportunity. In the early days there was little strategic thinking about the place of electronics and information technology in economic development. (Hobday, 1995:104; emphasis added)

In electronics, it is likely that direct technological and industrial intervention had little effect during the 1960s and 1970s. Left to the market, the TNCs and hundreds of latecomer firms began the industry by manufacturing simple products. ... Many small Taiwanese businesses mistrusted government, feared officialdom and kept their distance from state agencies. It is unlikely that specific programmes led directly to the start-up of many latecomer 
firms, or affected directly the strategies of large private companies such as Tatung, Sampo and Teco. ... Taiwan's vigor in the electronics industry depended primarily on strategies and abilities of entrepreneurs, engineers and managers. (Hobday, 1995:98)

This suggests that the government's role in the development of Taiwan's high-tech industries was not as the revisionists depict. The argument can be taken further. The electrical and electronics industries were already the second largest export sector in the mid-1960s, after textile products. By 1973, when ITRI was established, it had exceeded all manufacturing industries in terms of value added. Consequently, in this particular case at least, it seems more legitimate to say that the government was flexible enough to attach itself to the winners rather than judicious enough to pick the winners.

Efficacy of selective interventions. Nevertheless, the government did attempt to 'create winners' on some occasions. The most prominent example is the long series of failed attempts to promote the automobile industry. While admitting this as 'a case where protection has indeed had the predicted neoclassical results', Wade (1990:102) insists that 'it is an unusual case rather than the norm in Taiwan'. True, it was not the norm, but nor was it that unfamiliar in Taiwan. For example, there was the unsuccessful attempt to promote the aircraft industry, as detailed in Huang (1995); and there was a drive to encourage large-scale general trading companies, in the hope of unshackling Taiwanese firms from the control of Japanese sogo shosha (general trading companies) in international marketing. The government is still struggling with the aircraft programme, in a much lower gear, whereas the large-scale general trading companies programme was quietly terminated.

As for other policies discussed in this article, several studies have systematically examined their successes and failures. Smith (1997a) has succinctly summarised most of the findings. The results were mixed. For instance, the SEI was found to be quite effective in the initial stages of industrial development in encouraging investment, but the effectiveness of tax incentives had diminished over time. Investment credits indeed stimulated investment, but the goal of facilitating the acquisition of plant sites was not generally achieved. Government intervention clearly had some success in assisting high-tech industries, but strategic industry policy actually discriminated against the industries it aimed to promote (Smith, 1997b). By contrast, Pack and Lin (1997) find that as much as 40 per cent (the upper bound) of the annual 5 per cent total factor productivity growth in the manufacturing sector could be attributed to industrial policy; yet even on this favourable estimate, selective intervention would account for only 0.33 of a percentage point of economywide growth. As a result, they conclude that 'picking' or (more fashionably) 'creating' winners was not a major determinant of Taiwan's extraordinary growth. 


\section{Industry Policy and the East Asia Crisis: Taiwan vs Korea}

The current economic crisis in East Asia has confounded both sides of the debate on the causes of the economic miracle, which now looks more like a mirage. However, a consensus is emerging among observers to the effect that the crisis is partly rooted in government-directed lending, which in turn is closely related to the industry policies pursued by some of the troubled economies in the past few decades (Garnaut, 1998; Hong, 1998; Krugman, 1998). In order to implement selective interventions, as the revisionists correctly point out, the government required financial intermediaries to make credit available to designated borrowers at subsidised interest rates. As a result, the financial intermediaries were believed to be backed by the government in the form of explicit or implicit guarantees for their depositors. But the government's guarantees, real or illusory, fostered moral hazard, encouraging the intermediaries to take excessive risks. The financial market inevitably degenerated into a vicious circle of bad loans, bankruptcies, and bailouts.

The contrast between Taiwan and Korea is particularly striking in this respect. Both are frequently cited as exemplars of East Asian success. However, as Table 3 suggests, the Korean economy has so far performed far worse than Taiwan's. The difference in their industrial strategies provides at least a partial explanation of this. Korea's aggressive selective industrial policy concentrated economic power in the hands of a small number of large-scale industries, the chaebols, and wiped out the small enterprises. It also nurtured a complex, under-regulated bank system controlled by the government and the chaebols, whose inherent moral hazard created the preconditions for the present crisis. By contrast, selective policies have been far less evident or important in Taiwan. Although policies like the directed allocation of investment funds were widely applied and tended to favour large and public enterprises, they were by no means comparable to those of Korea. Indeed, the KMT government was reluctant to foster chaeboltype private business groups, partly because of the bitter lessons it learned on the Chinese mainland and partly because it distrusted Taiwanese entrepreneurs. As a result, thousands of small and mediumsized enterprises flourished, ironically helped more by an extraordinarily efficient informal financial market than by government-directed credit. This conspicuous contrast in industrial structure between the Korean and the Taiwanese models could largely explain the very different consequences of the Asian crisis in the two countries.

\section{Conclusion}

In this article I have pointed out some fundamental flaws in the revisionists' argument that the key to Taiwan's economic success lies in governing the market, and in particular its pursuit of selective industry policies. Four findings stand out.

First, the Taiwanese government did intervene extensively and selectively during various stages of industrial development, but most intervention was either a response to impending problems or politically motivated rather than the outcome of judicious selection. 
Second, there is no clear-cut evidence that selective intervention was effective. At most, selective industry policy could have boosted total factor productivity in some promoted sectors; however, the magnitude was of little significance in explaining Taiwan's phenomenal economy-wide growth. Even here, government could well not have 'picked' winners but rather attached itself to them.

Third, lack of information has led the revisionists to overlook the long-term trend in Taiwan's industrial policy towards liberalisation, including the movement from a 'planned economy' to a 'planned free economy' in the early import substitution phase.

Finally, Taiwan's much stronger economic performance than Korea's during the continuing East Asian economic crisis suggests that government-directed industrial policy based on easy money is self-defeating and is no recipe for fast and sustained economic growth.

\section{References}

Amsden, A. (1989), Asia's Next Giant: South Korea and Late Industrialization, Oxford University Press, New York.

(ed.) (1994), 'The East Asian Miracle: Economic Growth and Public Policy', World Development 22: 615-70.

Bhagwat, J. (1978), Anatomy and Consequences of Exchange Control Regimes, Ballinger, Cambridge.

Brautigam, D. (1995), 'The State as Agent: Industrial Development in Taiwan, 1952-1972', pp. 145-81 in H. Stein (ed.), Asian Industrialization and Africa, St. Martin's Press, New York.

Chan, S. \& C. Clark (1992), Flexibility, Foresight, and Fortuna in Tawwan's Development: Navigating between Scylla and Charybdis, Routledge, New York.

Council for Economic Planning and Development (CEPD) (various years), Taiwan Statistical Data Book, Taipei.

Dahlman, C. \& O. Sananikone (1997), 'Taiwan, China: Policies and Institutions for Rapid Growth', pp. 83-154 in D. Leipziger (ed.), Lessons from East Asia, University of Michigan Press, Ann Arbor.

Fei, J. (1992), 'Taiwan's Economic Development and Its Relation to the International Environment', pp. 3-23 in N. Wang (ed.), Taiwan's Enterprises in Global Perspective, M.E. Sharpe, New York.

(1995), 'A Bird's Eye View of Policy Evolution in Taiwan: An Introductory Essay', pp. 29-51 in K. Li, The Evolution of Policy behind Taiwan's Development Success (second edition), World Scientific Publishing Co., Singapore.

Fishlow, A., C. Gwin, S. Haggard, D. Rodrik \& R. Wade (eds) (1994), Miracle or Design? Lessons from the East Asian Experience, Overseas Development Council, Washington DC.

Galenson, W. (ed.) (1979), Economic Growth and Structural Change in Taiwan: The Postwar Experience of the Republic of China, Comell University Press, Ithaca.

Garnaut, R. (1998), 'The Financial Crisis: A Watershed in Economic Thought about East Asia', Asian Pacific Economic Literature 12: 1-11. 
Haggard, S. \& C. Pang (1994), 'The Transition to Export-Led Growth in Taiwan', pp. 47-89 in J. Aberbach, D. Dollar \& K. Sokoloff (eds), The Role of the State in Taiwan's Development, M.E. Sharpe, New York.

Hill, H. (1996), 'Indonesia's Industrial Policy and Performance: "Orthodoxy" vindicated', Economic Development and Cultural Change 45: 147-14.

Ho, S. (1978), Economic Development of Taiwan, 1860-1970, Yale University Press, New Haven.

Hobday, M. (1995), Innovation in East Asia: The Challenge to Japan, Edward Elgar, Aldershot

Hong, W. (1998), 'Sustained High Growth and Financial Chaos', Intemational Economic Journal 12: 141-53.

Hsu, J. (1997), Post-War Taiwan History, Wen Ying Tang Publishing Co., Taipei (in Chinese).

Huang, C. (1995), 'Industrial Upgrading and Multinational Corporations: A Bumpy Runway for Taiwan's Aircraft Industry', pp. 67-83 in S. Chan (ed.), Foreign Direct Investment in a Changing Global Political Economy, St. Martin's Press, New York.

Johnson, C. (1982), MITI and the Japanese Miracle: The Growth of Industrial Policy, 1925-1975, Stanford University Press, Stanford.

Krueger, A. (1978), Liberalization Attempts and Consequences, National Bureau of Economic Research, New York.

Krugman, P. (1994), 'The Myth of Asia's Miracle', Foneign Affairs 73(6): $62-78$.

- (1998), 'What Happened to Asia?', http://web.mitedu/krugman/www/

Kuo, S. (1997), Economic Policies: The Tawan Experience 1945-1995, Hwa-Tai Publishing Co., Taipei.

Lall, S. (1996), 'Paradigms of Development: The East Asian Debate', Oxford Development Studies 24: 111-31.

Li, K. (1994), 'Taiwan's Economic Development: Experiences and Strategies', Industry of Free China 81: 25-34.

— (1995), The Evolution of Policy Behind Tawan's Development Success (second edition) World Scientific Publishing Co., Singapore.

Lin, C. S. (1995), A Hundred Years' Experience of the Taiwan Economy, Sun-Tung Publishing Co., Taipei (in Chinese).

Lin, C. Y. (1973), Industrialization in Taiwan, 1946-1972: Trade and Import Substitution Policies for Developing Countries, Praeger, New York.

Pack, H. \& Y. Lin (1997), 'The Role of Industrial Policy in Taiwan's Development', paper presented at the conference on the Economics and Political Economy of Development at the Turn of the Century, Academia Sinica, Taipei.

Ranis, G. (1979), 'Industrial Development', pp. $206-62$ in W. Galenson (ed.), Economic Growth and Structural Change in Taiwan: The Postwar Experience of the Republic of China, Comell University Press, Ithaca. 
(1995), 'Another Look at the East Asian Miracle', The World Bank Economic Review 9: 50934.

- (1996), 'Successes and Failure of Development Experience since the 1980s', Economic Growth Center, Yale University, New Haven (Center Discussion Paper No. 762).

Riedel, J. (1996), 'Explaining Economic Growth in Taiwan', Business \& the Contemporary World 8: 223-44.

Smith, H. (1995), 'Industry Policy in East Asia', Asia Pacific Economic Literature 9: 17-39.

- (1997a), 'Taiwan's Industrial Policy in the 1980s: An Appraisal', Asian Economic Joumal 11: 133.

- (1997b), 'The Structure of Effective Assistance and Subsidy in Taiwan', The Singapore Economic Review 41: 57-83.

Tsai, P.-L. (1997), 'Paradigms of Development: The East Asian Debate: A Comment', Oxford Development Studies 25: 237-43.

Wade, R. (1990), Governing the Market: Economic Theory and the Role of Government in East Asian Industrialization, Princeton University Press, Princeton.

Wang, L. (1993), Oral History of K.T. Li: The Taiwan Experience, Zou-Yeh Culture Publishing Co., Taipei (in Chinese).

World Bank (1993), The East Asian Miracle: Economic Growth and Public Policy, Oxford University Press, Washington DC.

Yin, J. (1954), 'A Discussion on Industrial Policy for Taiwan', Industry of Free China 1: 1-14.

This article is part of a research project supported by the National Science Council of Taiwan under NSC 87-2415-H-007-006. I am grateful to Professor Hal Hill for very helpful comments on an earlier draft. My special thanks go to the editor for valuable suggestions and kind editing assistance. Constructive suggestions from two anonymous referees are also appreciated. Any remaining errors are my own responsibility. 